\title{
A new Late Jurassic halecomorph fish from the marine Vaca Muerta Formation, Argentina, southwestern Gondwana
}

\author{
Soledad Gouiric-Cavalli ${ }^{1,2}$ \\ ${ }^{1}$ División Paleontología Vertebrados, Museo de La Plata, Universidad Nacional de La Plata, Paseo del Bosque s/n, \\ W1900FWA La Plata, Argentina \\ ${ }^{2}$ CONICET, Avenida Rivadavia 1917, Ciudad Autónoma de Buenos Aires, Argentina \\ Correspondence to: Soledad Gouiric-Cavalli (sgouiric@fcnym.unlp.edu.ar)
}

Received: 14 March 2016 - Revised: 24 May 2016 - Accepted: 25 May 2016 - Published: 9 June 2016

\begin{abstract}
The knowledge of Mesozoic fish faunas of the Southern Hemisphere is still inadequate; the diversity and evolution of the Late Jurassic marine ichthyofaunas of Argentina remain unclear. One fish recovered from the Tithonian levels of the Los Catutos Member of the Vaca Muerta Formation, southwestern Argentina was considered a "caturid-like" halecomorph for almost 30 years. Recently, it was proposed that it could belong to the Pachycormiformes. A thorough comparative anatomical study of the material is conducted to test whether it could be included in $\dagger$ Caturidae or $†$ Pachycormidae. The specimen is assigned to $†$ Caturidae as a new genus and species: $†$ Catutoichthys olsacheri (http://zoobank.org/urn:lsid:zoobank.org:act: 6884876C-075C-433B-90B7-74187FC04C26, registered on 1 June 2016). The new taxon is based on a unique character combination, three of which are exclusive to $\dagger$ Catutoichthys olsacheri among caturids-diplospondylous vertebral column with triangular basidorsals and welldeveloped and fan-shaped basiventrals; neural and haemal spines strongly inclined to the body axis at an angle of $14^{\circ}$; a large number of infrahaemals; rounded amioid-type scales with an unornamented free field. The new taxon provides anatomical information useful for further understanding the anatomy and evolution of caturid fishes.
\end{abstract}

\section{Introduction}

Holostean (halecomorph and ginglymodian) fishes were taxonomically diverse in the Mesozoic but today are only represented by lepisosteiforms and amiiforms. Among amiiforms, the extinct caturid fishes have an intricate evolutionary and taxonomic history. $\dagger$ Caturidae was treated as a grade - a nonmonophyletic group - that comprised fishes that did not easily fit into other groups (e.g. Patterson, 1973; Schaeffer and Patterson, 1984), but most of those taxa are no longer considered caturids (see for instance, Bartram, 1975; Lambers, 1992, 1994, 1995; Grande and Bemis, 1998; Arratia, 2000, 2004, 2013; Arratia and Schultze, 2007). Prior to cladistic methodology - a process that provides hypotheses of the evolutionary history of taxa - caturids were interpreted as closely related to amiiforms (e.g. Lehman, 1966); phylogenetic analysis - techniques used to infer or estimate relationships - locates caturids as the sister group of amiids (e.g. Patterson, 1973; Olsen, 1984; Lambers, 1995; Gardiner, 1996; Grande and Bemis, 1998), closely related to ophiopsids (see Bartram, 1975; Schaeffer and Patterson, 1984), or as halecomorphs incertae sedis (Patterson and Rosen, 1977). Today, only four genera are considered to be caturids ( $\dagger$ Caturoidea sensu Grande and Bemis, 1998). These genera are grouped into two families: $\dagger$ Caturidae ( $\dagger$ Caturus, $\dagger$ Strobilodus, and $\dagger$ Amblysemius) and $\nmid$ Liodesmidae ( $\dagger$ Liodesmus).

$\dagger$ Caturoidea is currently interpreted as a monophyletic clade (Grande and Bemis, 1998, p. 611). However, the general morphology of most of $†$ Caturoidea genera is still undescribed (Arratia, 2004). Two hypotheses support the monophyly of the family $\dagger$ Caturidae, one based on a character combination (Lambers, 1995), the other based on a unique character (Grande and Bemis, 1998). Within †Caturidae, $\dagger$ Amblysemius and $†$ Caturus were considered monophyletic genera (see Lambers, 1992, p. 180, 1994), but †Caturus seems to be a "wastebasket" genus (see Gardiner, 1996, p. 130). For example, $†$ Strobilodus giganteus - which was considered a species of $\dagger$ Caturus by Lambers $(1992,1995)-$ is 
now regarded as a valid distinct taxon (see Schultze and Arratia, 2015).

Caturoids - as well as other basal halecomorph groups were primarily marine and only occasionally present in freshwater environments near marine seaways (Agassiz, 1833; Wagner, 1863; Lambers, 1992, 1994, 1995; Grande and Bemis, 1998, 1999). Caturids have mainly been recorded in Europe, whereas in Gondwana they are represented by isolated and fragmentary material recovered from freshwater environments in Africa (Saint-Seine and Casier, 1962; Dutheil, 1999; Murray, 2000) and Argentina (Cione et al., 1987; Bogan et al., 2013; Gouiric-Cavalli and Cione, 2015a). In Argentina they were found in continental Triassic deposits (Bogan et al., 2013) and marine Jurassic ones (Cione et al., 1987).

MOZ-Pv 3645 - a partially preserved fish - was collected at the El Ministerio quarry, where the Los Catutos Member (late middle-early late Tithonian) of the Vaca Muerta Formation crops out (Fig. 1). For more than 30 years MOZ-Pv 3645 was referred to as a caturid-like halecomorph (see Cione et al., 1987; Leanza and Zeiss, 1990; GouiricCavalli, 2013; Gouiric-Cavalli and Cione, 2015) but Bogan et al. (2013) suggested that it could be a teleosteomorph (†Pachycormiformes). The aim of this paper is to reassess whether MOZ-Pv 3645 is a halecomorph or a teleosteomorph by performing a comparative anatomical study of MOZ-Pv 3645 based on several well-preserved caturids and pachycormids. It is also expected that the anatomical information provided here will be meaningful for Southern Hemisphere fish diversity and evolutionary trends during the Jurassic.

Institutional abbreviations - BSPG, Bayerische Staatssammlung für und Historische Geologie, Munich, Bavaria, Germany; JM-E, Jura Museum Eichstätt (SOS indicates that the fish was recovered in the Solnhofen Limestone, Bavaria; ETT indicates that the specimen was recovered in sediments of the quarry of Ettling, Bavaria), Germany; MB, Museum für Naturkunde, Leibnitz-Institut für Evolutionsund Biodiversitätsforschung, Berlin, Germany; MLP, Museo de La Plata, División Paleontología Vertebrados, La Plata, Buenos Aires, Argentina; MOZ, Museo Provincial Dr. Prof. Juan Augusto Olsacher, Zapala, Neuquén, Argentina; SMNS, Staatliches Museum für Naturkunde, Stuttgart, Germany.

\section{Material and methods}

\subsection{Material preparation and observation techniques}

Mechanical preparation of the specimen was done using pneumatic tools, needles, and Widia tool tips. A latex peel was made to observe the structures preserved as impressions. The anatomical study was made under binocular microscope (Zeiss Stemi 2000-C) with different magnifications. Measurements were taken with a Vernier Caliper and with the software Image J using high-resolution photographs. The specimen was lightly coated with ammonium chloride before being photographed; photographs were taken using a digital camera Canon Rebel T2i with a compact macro lens Canon EF $50 \mathrm{~mm} \mathrm{f} / 2.5$. The drawings were done based on both photographs and use of the Leica Wild MS5 stereomicroscope with attached camera lucida. Digitization of the drawings was done with a Wacom tablet.

\subsection{Descriptive terminology}

Caudal endoskeletal terminology and caudal skeleton types follow Nybelin (1963, 1971, 1977), Arratia and Schultze (1992), and Schultze and Arratia (1986, 1989, 2013). The interpretation of caudal fin ray and associated elements follows Arratia (2008a, 2009). Vertebral centra terminology follows Schultze and Arratia $(1986,1989,2013)$ and Arratia et al. (2001). Scale terminology follows Schultze (1966, 1996, 2016). Meristic characters follows Grande and Bemis (1998).

\subsection{Material examined}

Several halecomorph and pachycormiform fishes were studied for comparative purposes, but only those members of family $\dagger$ Caturidae are listed below.

$\dagger$ Caturus furcatus: BSPG AS VII 263, JM-E SOS 3049, JM-E SOS 3365, JM-E SOS 3448, JM-E SOS 4023, JME SOS 3034, JM-E SOS 3057, MB 1381, MB 1583, SMNS 80144/23, SMNS 80440/50, SMNS 86901/37, SMNS 95361/3, SMNS 95361/8.

$\dagger$ Strobilodus giganteus: JM-E SOS 3573.

$\dagger$ Amblysemius pachyurus: JM-E SOS 3243a-b, JM-E SOS 4283, JM-E SOS 4302.

$\dagger$ Amblysemius bellicianus: JM-E SOS 4607.

\section{Systematic palaeontology}

\author{
Actinopterygii Cope, 1887 \\ Holostei Müller, 1845 \\ Halecomorphi Cope, 1872 [sensu Grande and Bemis, 1998] \\ Amiiformes Hay, 1929 \\ Caturoidea Owen, 1860 \\ Caturidae Owen, 1860 \\ Catutoichthys n. gen.
}

Diagnosis (based on a unique combination of characters, those marked with an asterisk [*] are autapomorphies): Medium-sized caturid fish with a low and triangular dorsal fin and a large and deeply forked caudal fin. Diplospondylous preural vertebral column with triangular basidorsals and well-developed and fan-shaped basiventrals [*]. 12 (or more) infrahaemals in the preural caudal region [*]. Neural and haemal spines strongly inclined to the body

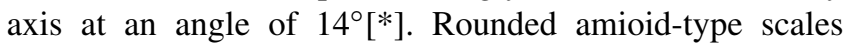
with an unornamented free field that lacks denticles and 


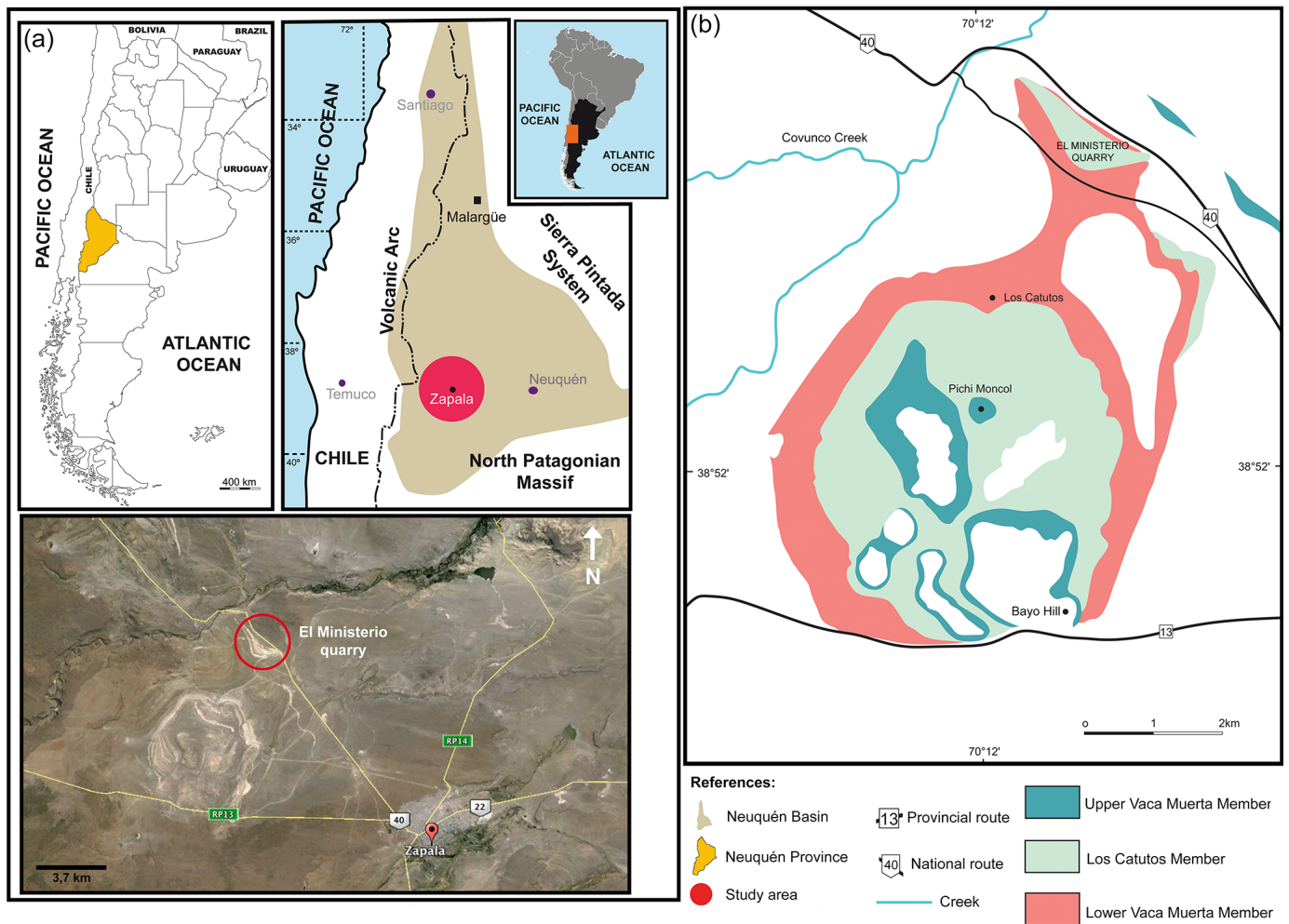

Figure 1. Geographic and geological maps of the studied area at Neuquén Province, Argentina. (a) Geographic location maps that show the Neuquén Province, Neuquén Basin extension, and the recovered specimen site - red circle in the aerial photograph (bottom left). (b) Geological map of the studied area, the three members coloured correspond to the Vaca Muerta Formation (modified from Leanza and Zeiss, 1990).

serrations $[*]$.

Derivation of name: Catuto refers to the type-bearing locality - Los Catutos; ichthys (Greek) meaning fish.

Catutoichthys olsacheri n. gen. et n. sp. (Figs. 2-7; Table 1)

Diagnosis: Same as genus.

Derivation of name: The specific name olsacheri refers to the Dr. Prof. Juan A. Olsacher Museum in which the specimen is deposited.

Holotype: MOZ-Pv 3645, a slab with a partially preserved fish. The specimen is incomplete and lacks most of the head bones but preserves some disarticulated and associated bones of the opercular series (these bones have been subject to minor dispersion); it also lacks the abdominal region.

\section{Anatomical description}

\subsection{Opercular series}

MOZ-Pv 3645 preserves a part of the opercular series (the opercular and subopercular) disarticulated and above on the slab, near the dorsal fin (Fig. 2). The opercular and subopercular are preserved as a lateral view impression on the slab. The opercular is roughly triangular and approximately twice as wide as it is high. The subopercular is also triangular but smaller than the operculum. The ornamentation of the opercular and subopercular consists of tiny punctures which cover the entire surface of the bone.

\subsection{Vertebral column}

MOZ-Pv 3645 preserves only the caudal (preural and ural) region of the vertebral column so that a summary of the entire vertebral series is impossible. The vertebrae are represented by thin chordacentra that surround but do not constrict the notochord and arcocentra (dorsal and ventral ones). MOZ-Pv 3645 preserves 29 dorsal arcocentra which carry well-developed anterior and posterior processes (Fig. 3). The ventral arcocentra are fan-shaped and bigger than the dorsal ones (Fig. 3); their precise number is difficult to establish 


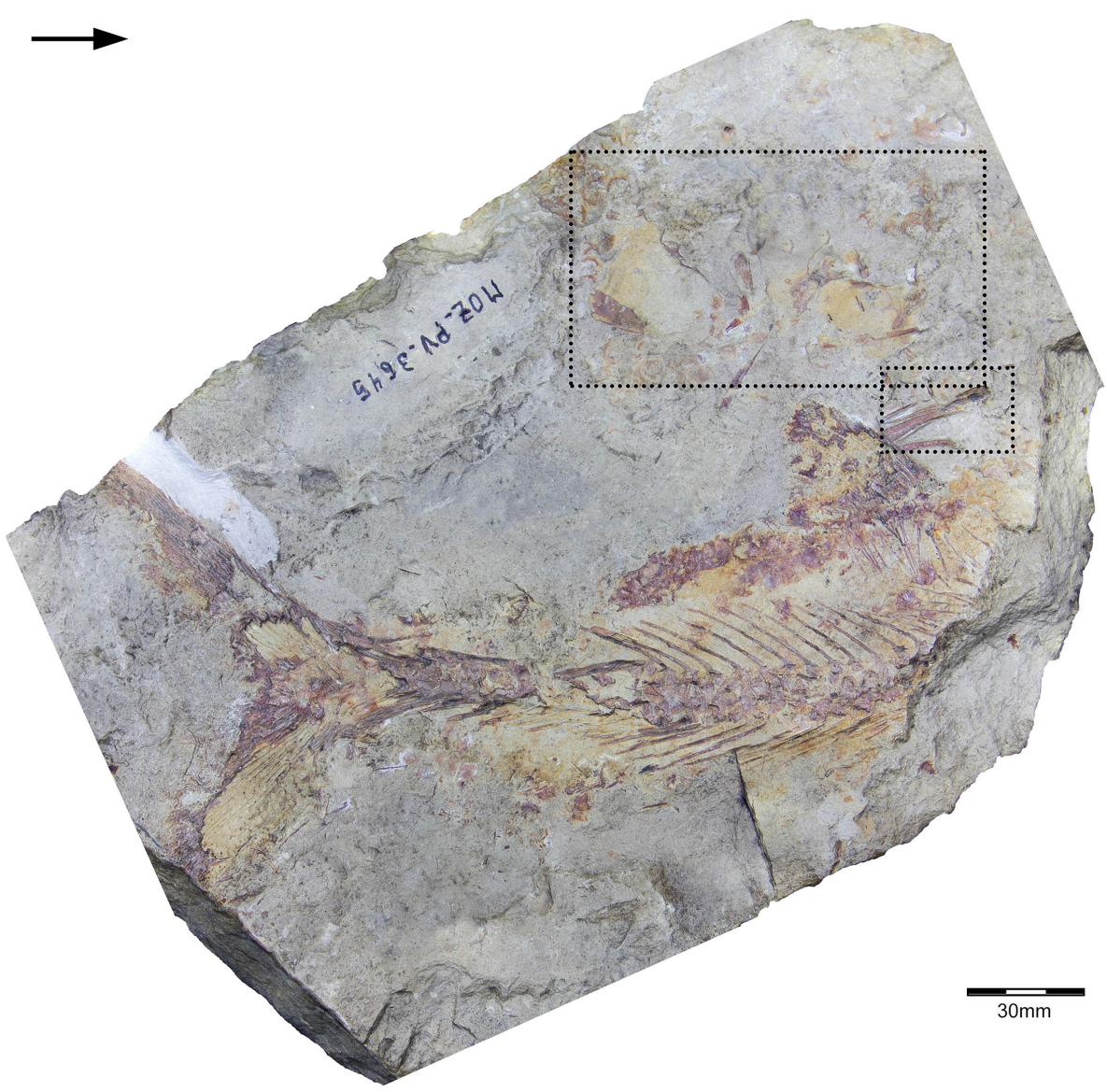

Figure 2. Catutoichthys olsacheri n. gen. et n. sp. MOZ-Pv 3645 from the Late Jurassic Vaca Muerta Formation, El Ministerio quarry, Argentina. Photograph of the holotype and only specimen. Dotted rectangles indicate disarticulated bones of the opercular series, rays, and scales. Arrow points anteriorly.

Table 1. Meristic data for the holotype and only specimen of $†$ Catutoichthys olsacheri n. gen. et n. sp. MOZ-Pv 3645.

\begin{tabular}{ll}
\hline Body depth & $\geq 75 \mathrm{~mm}$ \\
Dorsal fin base & ca. $36 \mathrm{~mm}$ \\
Caudal fin length (length of the longest preserved caudal fin ray) & $\geq 55 \mathrm{~mm}$ \\
Caudal peduncle depth & ca. $27 \mathrm{~mm}$ \\
Dorsal margin length between dorsal fin and caudal fin & ca. $127 \mathrm{~mm}$ \\
Preserved neural arcocentra & 29 \\
Preserved preural neural arcocentra & 25 \\
Preserved ural centra & 4 \\
Preserved diplospondylous vertebrae & 25 \\
Ossified infrahaemals & $\geq 12$ \\
Dorsal fin rays & $\geq 19$ \\
Branched dorsal rays & $\geq 18$ \\
Preserved hypurals & 5 to 8 \\
Preserved ossified epurals & 6 \\
\hline Total caudal fin rays & $>25$ \\
\hline
\end{tabular}




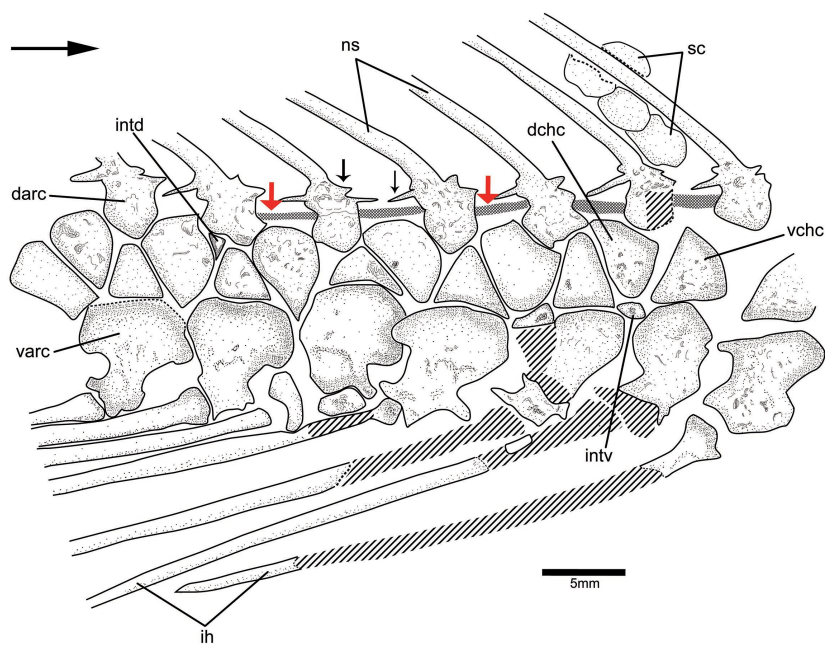

Figure 3. Catutoichthys olsacheri n. gen. et n. sp. MOZ-Pv 3645 from the Late Jurassic Vaca Muerta Formation, El Ministerio quarry, Argentina. Camera lucida drawing of a caudal portion of the vertebral column. Arrow points anteriorly. Simple hatched areas represent lost parts. Double hatched areas and red arrows represent the neural cord, which is preserved as an impression. Large black arrow points anteriorly. Small black arrows indicate the anterior and posterior processes of the dorsal arch. Abbreviations: darc, dorsal arcocentrum; dchc, dorsal chordacentrum; ih, infrahaemals; intd, interdorsal; intv, interventral; ns, neural spines; sc, scales; varc, ventral arcocentrum; vchc, ventral chordacentrum.

due to cluttering and/or lost of elements. The ventral arcocentra have short and robust anterior and posterior processes. Basidorsals and basiventrals are triangular. The neural cord is preserved as an impression (Fig. 3).

The preural caudal region of the vertebral column is diplospondylous. The anterior short preural neural arches articulate with long spine-like infrahaemals. The anterior preural caudal region bears 12 ossified infrahaemals and the posterior preural region 8 haemal spines. Infrahaemals and haemal spines have the same length. The ural region is monospondylous and composed of small and block-like neural arcocentra (Fig. 4). Despite the fact that the preural caudal region infrahaemals bend slightly towards the horizontal, at the preural and ural caudal region the neural and haemal spines bend strongly to the horizontal at an angle of $14^{\circ}$ with respect to the body axis (Fig. 2). The strong bending condition of preural and ural neural and haemal spines is present in fast-swimming neopterygians (e.g. Lund, 1967; Arratia and Lambers, 1996) and may be related to the strength of the caudal peduncle and the restriction of the lateral movement of the vertebrae. MOZ-Pv 3645 preural haemal spines are laterally expanded - spatulate - at their middle region.

\subsection{Dorsal fin}

The dorsal fin rays are supported by a series of pterygiophores that are about half the length of the longest rays. The

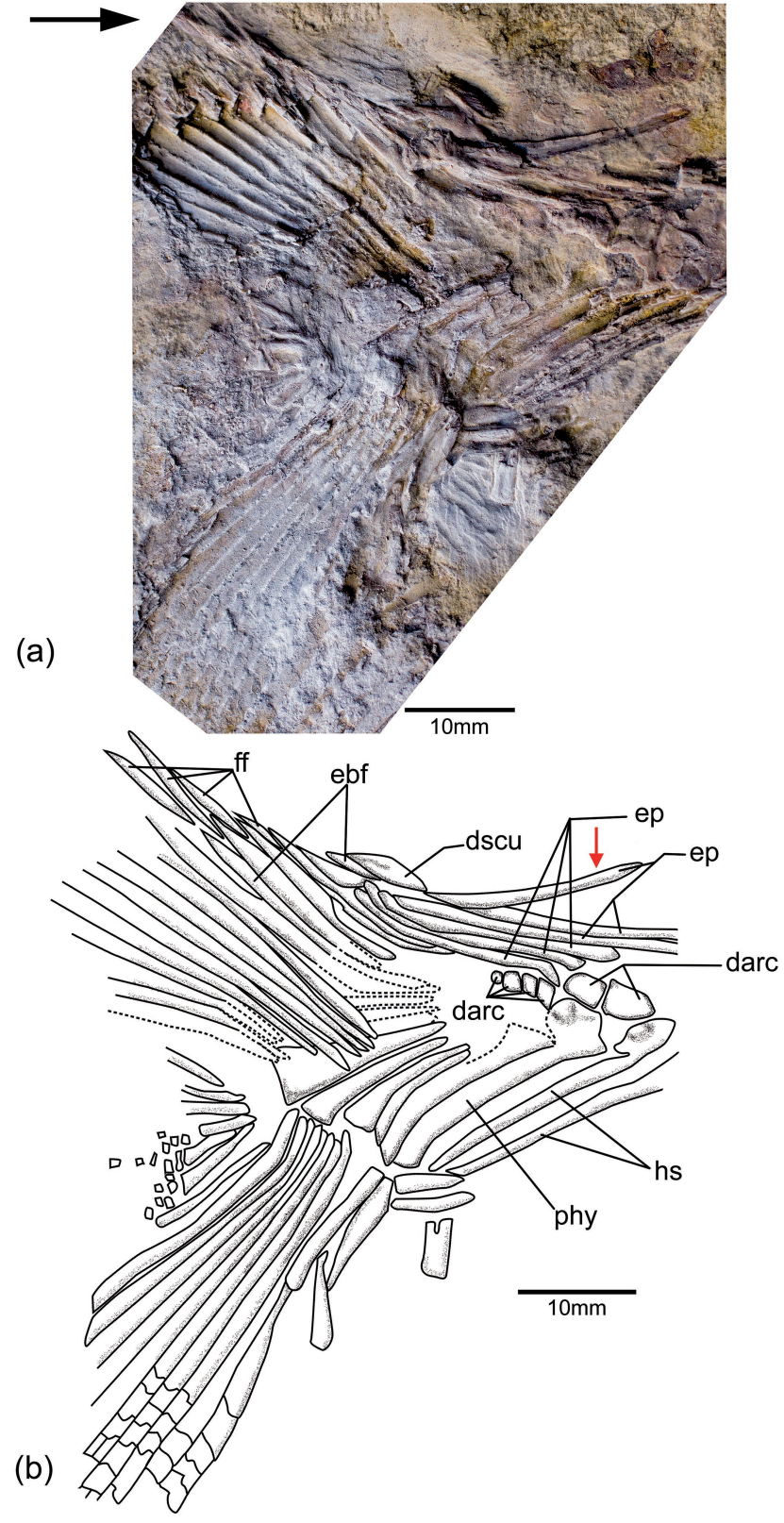

Figure 4. Catutoichthys olsacheri n. gen. et n. sp. MOZ-Pv 3645 from the Late Jurassic of Vaca Muerta Formation, El Ministerio quarry, Argentina. (a) Photograph of the caudal fin. (b) Camera lucida drawing of the caudal fin. Dotted lines show elements preserved as weak impressions. Black arrow points anteriorly. Red arrow indicates the long and convex epural. Abbreviations: darc, dorsal arcocentra; dscu, dorsal scute; ebf, epaxial basal fulcra; ep, epurals; ff, fringing fulcra; hs, haemal spines; phy, parhypural.

anterior pterygiophores are roughly thin, long, and without flanges; the posterior ones are shorter. The dorsal fin is triangular and the first principal ray is the longest. The posterior margin of the dorsal fin seems to be straight to slightly falcate (Fig. 5). At least 18 principal rays and 1 procurrent ray are preserved, but their total number cannot be established with 


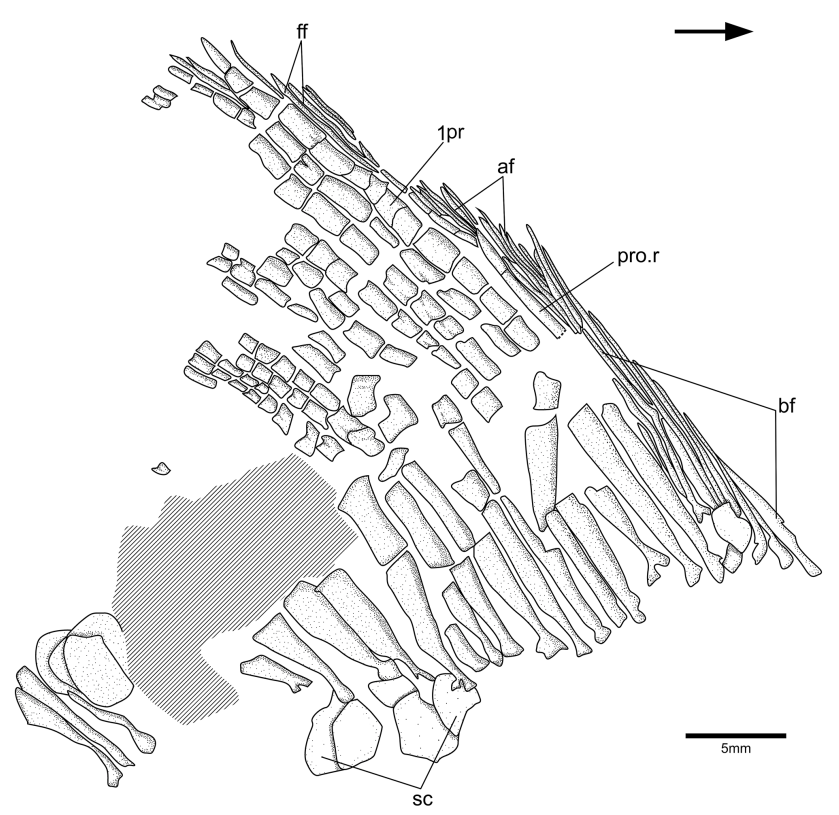

Figure 5. Catutoichthys olsacheri n. gen. et n. sp. MOZ-Pv 3645 from the Late Jurassic Vaca Muerta Formation, El Ministerio quarry, Argentina. Camera lucida drawing of the dorsal fin. Arrow points anteriorly. Hatched areas represent lost rays. Abbreviations: af, accessory fulcra; bf, basal fulcra; ff, fringing fulcra; proc.r, procurrent ray; sc, scales; $1 \mathrm{pr}$, first principal ray.

certainty due to preservation. All the dorsal fin rays are segmented and bifurcation occurs at the distal portion of the ray. Dorsal fin rays are expanded at their proximal region; at least the most posterior eight dorsal fin rays appear to have a more expanded proximal region than the anterior ones (Fig. 5). A lanceolate, thin basal fulcrum composes the basal fulcra that precede the fin. The fringing fulcra form the leading edge of the dorsal fin, resembling Pattern $\mathrm{C}$ described by Arratia (2009). A bundle of accessory elements - accessory fulcra - is placed between the dorsal procurrent ray and the basal fulcra (Fig. 5). This condition is also present in $†$ Caturus furcatus (personal observation, 2015, of JM SOS 3049). At least 17 pterygiophores are preserved in MOZ-Pv 3645; many of them are displaced from their original position.

\subsection{Caudal fin endoskeleton, fin rays, fulcra, and scutes}

MOZ-Pv 3645 caudal endoskeleton is polyural, which means that more than one ural centrum is associated with a single hypural (Nybelin, 1963, 1977; Schultze and Arratia, 1989). The ural region is composed of calcified block type neural arcocentra (Fig. 4). This ural arcocentra morphology (block type) seems to be unique to caturids among neopterygians (Patterson, 1973; Schaeffer and Patterson, 1984; Lambers, 1992, 1995).

The caudal fin is deeply forked; its rays are well ossified and have two portions: an unsegmented proximal one and a segmented distal one (Fig. 4, 6). Each caudal ray branches 5 to 10 times at the distal part of the segmented zone. As the rays become progressively more branched, the segments become thinner and smaller and the number of branches are difficult to establish with certainty. At least 10 principal fin rays constitute the dorsal lobe of the caudal fin; the first two are the shorter. A large, well-ossified, slender, and laterally expanded basal fulcrum precedes the bases of the dorsal and ventral caudal fin lobes.

The proximal ends of the epaxial fin rays partly overlap the hypurals, being located at an angle of about $50^{\circ}$ in relation to the body axis (Fig. 4). The basal fulcra associated with the dorsal caudal fin lobe are composed of at least six basal fulcra (Fig. 4). Each dorsal basal fulcrum broadly overlaps the preceding one. The epaxial basal fulcra are supported by well-ossified and long epurals. Accessory fulcra are irregular in their distribution over the epaxial caudal fin lobe: some accessory fulcra are located between two successive basal fulcra; meanwhile others are located between successive fringing fulcra (Figs. 4-6).

A rhombic scute precedes the epaxial basal fulcra (Fig. 4). Urodermals - which are present on caudal fin rays of the dorsal lobe of almost all caturids - are not preserved in the specimen studied here. A long and concave epural covers the following five epurals (Fig. 4). The presence of a long and concave epural covering the subsequent epurals is a character also present in those $†$ Caturus specimens examined here (see also Lund, 1967, fig. 5), but the number of epurals below the long convex epural seems to vary between 3 and 6. Contrary to $†$ Caturus and MOZ-Pv 3645, $\dagger$ Amblysemius pachyurus seems to have two long, straight, and downwardsinclined epurals overlapping the following ones (personal observation of JM-E SOS 4283). The basal fulcra associated with the ventral lobe seem to be formed by less than six elements, but the exact number cannot be established due to preservation. A ventral scute is not preserved.

\subsection{Squamation}

MOZ-Pv 3645 squamation is partially preserved, being especially well-preserved in front of the dorsal fin; some scales are disarticulated and displaced. The size and shape of the preserved scales seems to be constant. The scales are elasmoid and of the so-called amioid type (Schultze, 1966, 1996, 2016). Each scale is relatively large, rounded, and thin. The posterior free field - preserved in some scales - has a smooth edge and is devoid of denticles and/or serrations, which are commonly present in caturids (i.e. †Caturus; see Agassiz, 1833, p. 115; H.-P. Schultze, personal communication, 2015). Also, the free scale field is shiny and lacks tubercles. The anterior covered field has weak ridges and lacks concentric rings and radii (Fig. 7). Elasmoid scales of an amioid type occur in different actinopterygians (i.e. amiids, caturids, teleosteomorphs, and teleosts). The morphology of the scales of $\dagger$ Catutoichthys olsacheri is different from those of pachy- 


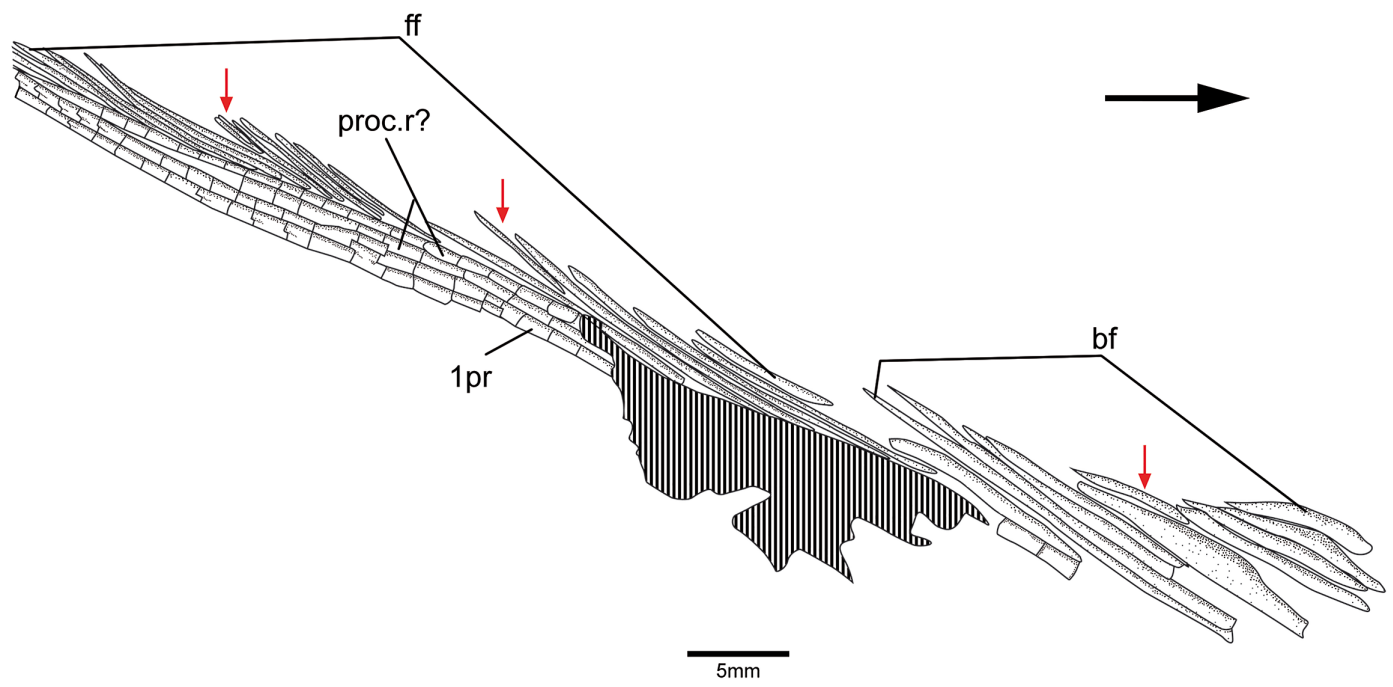

Figure 6. Catutoichthys olsacheri n. gen. et n. sp. MOZ-Pv 3645 from the Late Jurassic Vaca Muerta Formation, El Ministerio quarry, Argentina. Camera lucida drawing of the distal part of the dorsal caudal fin lobe, which is not shown in Fig. 5. Hatched areas represent lost rays. Red small arrows indicate accessory fulcra. Black arrow points anteriorly. Abbreviations: bf, basal fulcra; ff, fringing fulcra; proc.r?, procurrent rays?; 1pr, first principal caudal fin ray.
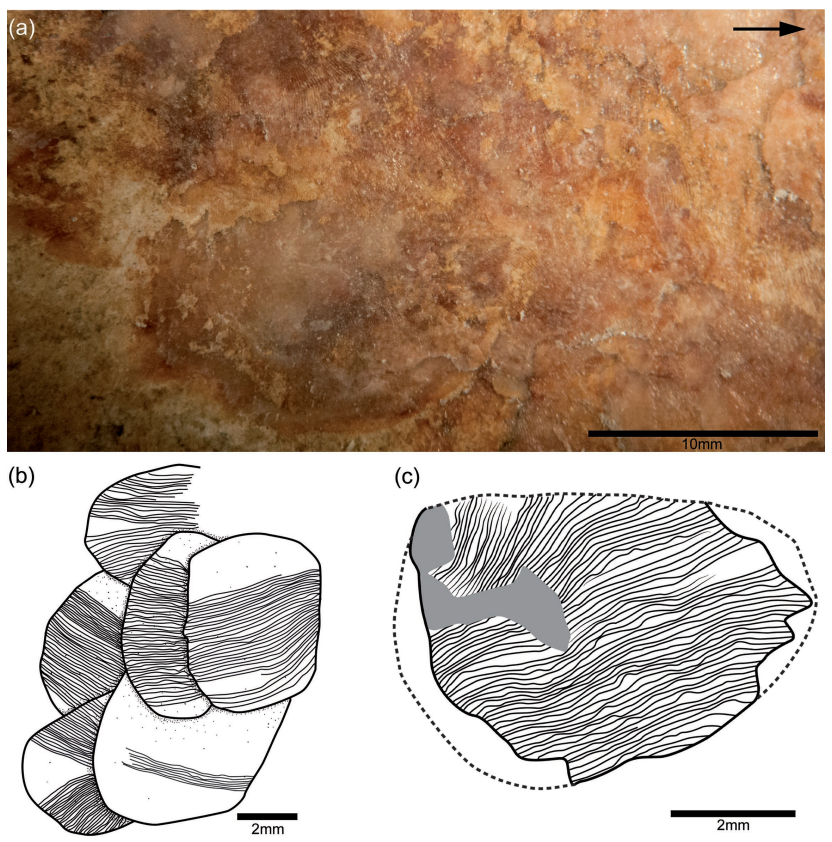

Figure 7. Scales of Catutoichthys olsacheri n. gen. et n. sp. MOZPv 3645 from the Late Jurassic Vaca Muerta Formation, El Ministerio quarry, Argentina. (a) Photograph of scales located below the dorsal fin. (b) Camera lucida drawing of a series of scales. (c) Camera lucida drawing of one partially preserved scale. Grey zone indicates a broken or lost part of the scale. Dotted lines follow the anterior and posterior broken scale margins. Arrow points anteriorly. cormids, which are rhombic and extremely small (e.g. Lambers, 1992).

\section{Discussion}

While almost nothing is known about Mesozoic caturoid diversity in Gondwana, they are represented by two families - †Liodesmidae and $\dagger$ Caturidae - in Europe (e.g. Lambers, 1992; Grande and Bemis, 1998). Among †Caturidae, three genera are recognized: $\dagger$ Caturus (with several species), $\dagger$ Amblysemius (with two species), and Strobilodus (with one species) (Lambers, 1992; Schultze and Arratia, 2015). Nonetheless, the family $\dagger$ Caturidae needs a thorough revision (e.g. Schaeffer and Patterson, 1984; Lambers, 1992; Arratia, 2004).

MOZ-Pv 3645 was firstly mentioned and illustrated by Cione et al. (1987); in that publication the specimen was referred to as a halecomorph caturid-like fish based on similarities between the caudal skeleton structure and scales with those present in $\dagger$ Caturus (see Cione et al., 1987; Leanza and Zeiss, 1990). In contrast, Bogan et al. (2013) proposed that the specimen might belong to $\dagger$ Pachycormiformes based on "a close inspection of the specimen osteology", but they did not list any anatomical characters supporting this perspective (Bogan et al., 2013, p. 191).

The detailed study presented here reveals anatomical characters that support the specimen's systematic location amongst halecomorphs, as a member of $\dagger$ Caturidae. Among other characters (e.g. presence of big and well-developed amioid type scales, a long epural that covers the subsequent ones, most of dorsal lobe caudal fin rays supported by the 
hypurals, spatulate haemal spines, preural haemal and neural spines strongly inclined to the horizontal, size and shape of the dorsal fin, number of principal dorsal fin rays), MOZPv 3645 shows block-like ural neural arcocentra, a character considered unique to $\dagger$ Caturidae among actinopterygians (Lambers, 1992; Grande and Bemis, 1998). In addition, MOZ-Pv 3645 seems to be closer in size to $†$ Caturus than $\dagger$ Amblysemius or $\dagger$ Strobilodus due to the shape of the long epural that covers the following ones, size of scales, and general body size. However, ornamentation of the scales of MOZ-Pv 3645 is different to those present in $\dagger$ Caturus.

Nevertheless, there are similarities between $\dagger$ Catutoichthys olsacheri (and all caturids) and pachycormids, e.g. presence of a deeply forked caudal fin, dorsal and ventral spines of the caudal region strongly inclined to the horizontal, and the presence of amioid-type scales. The $\dagger$ Catutoichthys olsacheri scale morphology and size sets this taxon apart from those scaled pachycormids which also have amioid-type scales, but the scales are small and rhombic. Also, the absence of ornamentation (denticles and serrations) in the free scale field of $\dagger$ Catutoichthys olsacheri seems to be unique to this taxon within $†$ Caturoidea. Moreover, the MOZ-Pv 3645 dorsal fin shows differences when it is compared with those of pachycormiforms; for instance: MOZ-Pv 3645 has a lower number of principal fin rays (18 to 20 rays) than pachycormids (33 to 45 rays; see Lambers, 1992; Arratia and Schultze, 2013); each dorsal fin ray of MOZ-Pv 3645 has several short segments. On the contrary, pachycormid dorsal fin rays have scarce segmentation (or no segmentation at all; see Liston, 2010) with fewer and considerably long segments. Both MOZ-Pv 3645 and pachycormids have finely branched distal portions of the dorsal fin rays. The dorsal fin fringing fulcra distribution pattern seems to be different between MOZ-Pv 3645 and pachycormids. While MOZ-Pv 3645 has well-developed fringing fulcra with a uniform distribution over the entire margin of the dorsal fin; in pachycormids the fringing fulcra seem to have a few widely spaced fringing fulcra (Arratia and Schultze, 2013). Height and general morphology of the dorsal fin is also different. While the dorsal fin of MOZ-Pv 3645 is low and long, the rays and fulcra are gently curved backward, and the length of the fin base is approximately equivalent to the height of the dorsal fin (measured perpendicularly); the pachycormid dorsal fin is comparatively tall and short, their fin rays are slightly inclined backward, and the fin base represents ca. one and a half times the height of the fin.

Focusing on the angle in which the neural and haemal spines are located in relation to the body axis - a character easily observed among pachycormids and caturids - some differences can be highlighted. For instance, in $\dagger$ Orthocormus roeperi the neural spines are disposed at an angle of ca. $18^{\circ}$ with respect to the body axis and the haemal ones at about $20^{\circ}$. Meanwhile, $\dagger$ Caturus furcatus has both neural and haemal spines located at an angle of approximately $20^{\circ}$ with respect to the body axis (personal observa- tion, 2015, of JME-SOS 3049). The angle in which the neural and haemal spines are related to the body axis is lower $\left(14^{\circ}\right)$ and seems to be unique to $\dagger$ Catutoichthys olsacheri among $†$ Caturoidea. MOZ-Pv 3645 lacks a conspicuous hypural plate, the sparse (or lack of) segmentation of caudal and dorsal fin rays, and the scaly caudal apparatus which are common to almost all pachycormids (Liston, 2010; Arratia and Lambers, 1996; Arratia and Schultze, 2013; Liston et al., 2013; personal observation, 2015, in several pachycormids specimens). Furthermore, pachycormids caudal basal fulcra are composed of many long and slender fulcra (Arratia and Lambers, 1996), whereas MOZ-Pv 3645 caudal basal fulcra are formed by comparatively fewer and shorter fulcra.

MOZ-Pv 3645 is described here as a new genus and species, $\uparrow$ Catutoichthys olsacheri on the basis of its unique character combination. Also, some of the characters shown by the new specimen are unique within $†$ Caturoidea (i.e. fan-shaped basiventrals, relatively large scales with a smooth posterior free margin, neural and haemal spines strongly inclined to the body axis at an angle of $14^{\circ}$ ).

\section{Palaeobiogeographic comments}

Amiiformes inhabited marine and freshwater environments. They had a widespread distribution during Mesozoic times (e.g. Grande and Bemis, 1998). While members of $\dagger$ Caturidae are mainly recorded in the Northern Hemisphere, only two caturid fishes have been reported from the Southern Hemisphere - both come from Argentina (Cione et al., 1987; Bogan et al., 2013; Gouiric-Cavalli and Cione, 2015a).

The first well-known caturid is $†$ Caturus heterurus Agassiz, 1839 from the Lower Jurassic (Sinemurian) of the United Kingdom (Martín-Abad and Poyato-Ariza, 2013a). Despite the fact that the oldest caturid fishes seem to have been recorded in the Upper Triassic sediments of Europe - specifically, Austria and Spain (see discussion in Lambers, 1992, p. 105) - and South America - Argentina (Bogan et al., 2013), some of these assessments are considered doubtful (Cartanyá, 1999). In light of the fact that $\dagger$ Caturus seems to be one of the most commonly cited fish taxa in European Mesozoic associations (e.g. Agassiz, 1834; von Zittel, 1887; Sauvage, 1893; Woodward, 1895; Wenz, 1967; Beltan, 1972; Lambers, 1992; Poyato-Ariza et al., 1999; Martín-Abad and Poyato-Ariza, 2013a, b), European remains need to be reviewed. In addition, due to the doubtful assignation of the Triassic caturid records from Europe and Argentina, a review of these specimens is recommended here.

Caturids could be considered ichthyophagous fishes due to their dentition and general body shape, inhabiting the nearshore environment (Martín-Abad and Poyato-Ariza, 2013a). This may have affected their capacity for range expansion and distribution over time (Martín-Abad and Poyato-Ariza, 2013a). Prior to this study, only two caturids showed a scattered distribution through the Hispanic Cor- 


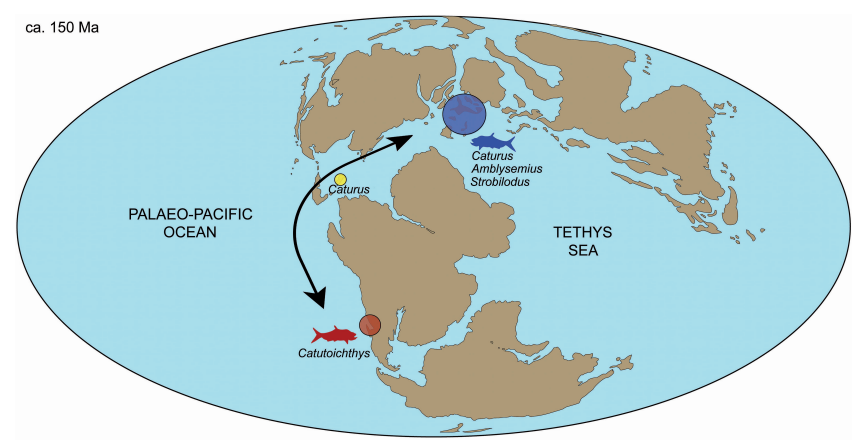

Figure 8. Distribution of Late Jurassic palaeobiogeographic caturids. Blue circle indicates European genera, yellow circle indicates Cuban genus, and the red circle indicates the Argentinian taxon. The arrow indicates dispersion through the Hispanic Corridor. Palaeobiogeographic map based on Ron Blakey Paleomaps (www.cpgeosystems.com/paleomaps.html).

ridor: $\dagger$ Caturus dartoni (Eastman, 1899) from the LowerMiddle Jurassic of South Dakota, United States (Schaeffer and Patterson, 1984; Hunt and Spencer, 1993), and $\dagger C$. deani Gregory, 1923 from the Upper Jurassic (OxfordianKimmeridgian) of Cuba (Gregory, 1923; Iturralde-Vinent and Ceballos-Izquierdo, 2015).

The presence of caturids - as well as other fish groups - in both the Upper Jurassic of Argentina and some European countries supports a connection between the Tethys and the Palaeo-Pacific trough marine corridors (e.g. Arratia, 1994, 2015; Arratia and Hikuroa, 2010; Gouiric-Cavalli, 2015; Gouiric-Cavalli and Cione, 2015; Fig. 8). Moreover, the new taxon described here implies that the opening of the marine Hispanic Corridor in the Early Jurassic contributed to the western dispersion of caturids - and other coastal taxa - during the Early-Middle Jurassic, with further speciation in Patagonia during the Late Jurassic. However, due to the still relatively poor knowledge of Late Jurassic PalaeoPacific ichthyofaunas - which have been demonstrated to be highly diverse, containing endemic taxa (e.g. Arratia, 1994, 2008b; Gouiric-Cavalli, 2013, 2015; Gouiric-Cavalli and Cione, 2015b) - it is possible that radiation events occurred at the same time in both the western Tethys and the Palaeo-Pacific seas.

$\dagger$ Catutoichthys olsacheri constitutes not only the most complete but also the first Jurassic caturid specimen described from Gondwana and extends the geographic record of the family †Caturidae to the Palaeo-Pacific, where the group is largely unknown.

\section{Conclusions}

A thorough anatomical study of MOZ-Pv 3645 has been presented, providing new information relating to Jurassic fish morphological disparity in Argentina and Gondwana in general. The characters exhibited by MOZ-Pv 3645 allow its establishment as a new taxon within $†$ Caturidae (contra Bogan et al., 2013), being the first representative of the family described in detail for the Upper Jurassic (Tithonian) of Argentina and Gondwana. This study provides new anatomical information - relating to fulcra and fringing fulcra of unpaired fins, anatomy of the caudal endoskeleton, vertebral column, and scales - that could be useful in further studies on caturids and other related actinopterygians. This Argentinian caturid fish is further compelling evidence of the role of the Southern Hemisphere in the diversification of some actinopterygian groups. Still, the relationships and comparative diversity between Northern Hemisphere and Southern Hemisphere ichthyofaunas, as well as the timing of taxa divergence, remain unknown (Gouiric-Cavalli, 2013, 2015; Gouiric-Cavalli and Cione, 2015a, b). The new taxon extends the stratigraphic and geographic record of the family $\dagger$ Caturidae to the Late Jurassic-Tithonian of South America at the Palaeo-Pacific Ocean, where the group is barely known.

Acknowledgements. I thank the following people for allowing me to study material under their care: M. Kölbl-Ebert and M. Ebert (JM), R. Böttcher (SMNS), F. Witzmann (MB), O. Rauhut and M. Möser (BSPG), and A. Garrido and B. Boillini (MOZ). I am grateful to G. Arratia and H.-P. Schultze for their support and useful discussions and comments on an early version of the manuscript. I thank to H.-P. Schultze, who kindly shared some unpublished data, which were tremendously useful in the scale discussion section of this paper. I would like to thank to my colleagues G. Arratia, A. Cione, L. Rasia, L. Acosta Burllaile, and L. Pérez for their support and help with bibliography and preparation techniques. I thank J. Liston (Vivacity Peterborough Museum), who reviewed the English and provided constructive comments. L. Rasia digitalized some of the maps. I thank the reviewers, H. Martín-Abad and G. Arratia, for their comments and suggestions, which helped to improve the work presented.

Edited by: F. Witzmann

Reviewed by: G. Arratia and H. Martín-Abad

\section{References}

Agassiz, L.: Recherches sur les Poissons Fossiles, Neuchâtel et Soleure, Petitpierre, 5, 1798 pp., 1833-1843.

Agassiz, L.: Abgerissene Bemerkungen über fossile Fische, Neues Jahrb. für Mineral. Geognosie, Geol. und Petrefaktenkd., 4, 379390, 1834.

Arratia, G.: Phylogenetic and paleobiogeographic relationships of the varasichthyid group (Teleostei) from the Late Jurassic of 
Central and South America, Rev. Geol. Chile., 21, 119-165, 1994.

Arratia, G.: New teleostean fishes from the Jurassic of southern Germany and the systematic problems concerning the "pholidophoriforms", Paläontol. Zeit., 74, 113-143, 2000.

Arratia, G.: Mesozoic halecostomes and the early radiation of teleost, in: Mesozoic Fishes 3 - Systematics, Palaeoenvironments and Biodiversity, edited by: Arratia, G. and Tintori, A., 279-315, Verlag Dr. Friedrich Pfeil, München, 2004.

Arratia, G.: Actinopterygian postcranial skeleton with special reference to the diversity of fin ray elements, and the problem of identifying homologies, in: Mesozoic Fishes 4 - Homology and Phylogeny, vol. 4, edited by: Arratia, G., Schultze, H.-P., and Wilson, M. V. H., 49-101, Verlag Dr. Friedrich Pfeil, München, 2008a.

Arratia, G.: The varasichthyid and other crossognathiform fishes, and the break-up of Pangaea, in: Fishes and the Break-up of Pangea, edited by: Cavin, L., Longbottom, A., and Richter, M., 71-92, Geological Society of London Special Publications, 2008b.

Arratia, G.: Identifying patterns of diversity of the actinopterygian fulcra, Acta Zool., 90, 220-235, 2009.

Arratia, G.: Morphology, taxonomy, and phylogeny of Triassic pholidophorid fishes (Actinopterygii, Teleostei), J. Vertebr. Paleontol., 33, 1-138, 2013.

Arratia, G.: Los peces osteíctios fósiles de Chile y su importancia en los importancia en los contextos paleobiogeográficos y evolutivos, Rev. Mus. Hist. Nat. Chile, 63, 35-83, 2015.

Arratia, G. and Hikuroa, D. C. H.: Jurassic fishes from Latady Group, Antarctic Peninsula, and the oldest teleosts from Antarctica, J. Vertebr. Paleontol., 30, 1331-1342, 2010.

Arratia, G. and Lambers, P. H.: The caudal skeleton of pachycormiforms: Parallel evolution?, in: Mesozoic Fishes - Systematics and Paleoecology, edited by: Arratia, G. and Viohl, G., 191-218, Verlag Dr. Friedrich Pfeil, München, 1996.

Arratia, G. and Schultze, H.-P.: Reevaluation of the caudal skeleton of certain actinopterygian fishes: III. Salmonidae. Homologization of caudal skeletal structures, J. Morphol., 214, 187-249, 1992.

Arratia, G. and Schultze, H.-P.: Eurycormus - Eurypoma, two Jurassic actinopterygian genera with mixed identity, Foss. Rec. Mitt. aus dem Mus. für Naturkd., 10, 17-37, 2007.

Arratia, G. and Schultze, H.-P.: Outstanding features of a new Late Jurassic pachycormiform fish from the Kimmeridgian of Brunn, Germany and comments on current understanding of pachycormiforms, in: Mesozoic Fishes 5 - Global Diversity and Evolution, edited by: Arratia, G., Schultze, H.-P., and Wilson, M. V. H., 87-120, Verlag Dr. Friedrich Pfeil, 2013.

Arratia, G., Schultze, H. P., and Casciotta, J.: Vertebral column and associated elements in dipnoans and comparison with other fishes: Development and homology, J. Morphol., 250, 101-172, 2001.

Bartram, A. W. H.: The holostean fish genus Ophiopsis Agassiz, Zool. J. Linn. Soc., 56, 183-205, 1975.

Beltan, L.: La faune ichthyologique du Muschelkalk de la Catalogne, Mem. Real Acad. Cienc. Artes Barcelona, 41, 281-325, 1972.

Bogan, S., Taverne, L., and Agnolin, F.: First Triassic and oldest record of a South American amiiform fish: Caturus sp. from the
Los Menucos Group (lower Upper Triassic), Río Negro province, Argentina, Geol. Belgica, 16, 191-195, 2013.

Cartanyà, J.: An overview of the Middle Triassic actinopterygians from Alcover, Montral and El Pinetell (Catalonia, Spain), in: Mesozoic Fishes 2 - Systematics and Fossil Record, edited by: Arratia, G. and Schultze, H.-P., 535-551, Verlag Dr. Friedrich Pfeil, München, 1999.

Cione, A. L., Gasparini, Z., Leanza, H. A., and Zeiss, A.: Marine oberjurassische Plattenkalke in Argentinien (Ein erster Forschungsbericht), Archeopt., 5, 13-22, 1987.

Cope, E. D.: Observations on the systematic relations of the fishes, Proc. Am. Assoc. Adv. Sci., 20, 317-347, 1872.

Cope, E. D.: Zittel's Manual of Paleontology, Am. Nat., 17, 10141019, 1887.

Dutheil, D. B.: An overview of the freshwater fish fauna from the Kem Kem beds (Late Cretaceous: Cenomanian) of southeastern Morocco, in: Mesozoic Fishes 2 - Systematics and Fossil Record, edited by: Arratia, G. and Schultze, H.-P., 553-563, Verlag Dr. Friedrich Pfeil, München, 1999.

Eastman, Ch. R.: Jurassic fishes from Black hills of South Dakota, Bull. Geol. Soc. Am., 10, 397-408, 1899.

Gardiner, B.: Interrelationships of basal neopterygians, in: Interrelationships of fishes, edited by: Stiassny, M. L. J., Parenti, L. R., and David, J. G., 117-146, Academic Press, San Diego, 1996.

Gouiric-Cavalli, S.: Sistemática y relaciones biogeográficas de los peces del Titoniano (Jurásico tardío) de la Cuenca Neuquina de Argentina, 583 pp., Unpublished Ph.D. thesis, Facultad de Ciencias Naturales y Museo, Universidad Nacional de La Plata, Argentina, 583 pp., 2013.

Gouiric-Cavalli, S.: Jonoichthys challwa gen. et sp. nov., a new Aspidorhynchiform (Osteichthyes, Neopterygii, Teleosteomorpha) from the marine Upper Jurassic sediments of Argentina, with comments about paleobiogeography of Jurassic aspidorhynchids, C. Ren. Pal., 14, 291-304, 2015.

Gouiric-Cavalli, S. and Cione, A. L.: Fish faunas from the Late Jurassic (Tithonian) Vaca Muerta Formation of Argentina: One of the most important Jurassic marine ichthyofaunas of Gondwana, J. South Am. Earth Sci., 63, 114-124, 2015 a.

Gouiric-Cavalli, S. and Cione, A. L.: Notodectes is the first endemic pachycormiform genus (Osteichthyes, Actinopterygii, Pachycormiformes) in the Southern Hemisphere, J. Vertebr. Paleontol., 35, e933738, doi:10.1080/02724634.2014.933738, 2015b.

Grande, L. and Bemis, W. E.: A Comprehensive Phylogenetic Study of Amiid Fishes (Amiidae) Based on Comparative Skeletal Anatomy. an Empirical Search for Interconnected Patterns of Natural History, J. Vertebr. Paleontol., 18, 1-696, 1998.

Grande, L. and Bemis, W. E.: Historical biogeography and historical paleoecology of Amiidae and other halecomorph fishes, in: Mesozoic Fishes 2 - Systematics and Fossil Record, edited by: Arratia, G. and Schultze, H.-P., 413-424, Verlag Dr. Friedrich Pfeil, München, 1999.

Gregory, B. Y. W. K.: A Jurassic fish fauna from western Cuba, with an arragement of the families of holostean ganoid fishes, Bull. Am. Museum Nat. Hist., 4, 223-242, 1923.

Hay, O. P.: Second bibliography and catalogue of the fossil Vertebrata of North America, Publ. Carnegie Inst. Washingt., 390, 1-2003, 1929.

Hunt, A. P. and Spencer, L. G.: Jurassic Vertebrates of New Mexico, Vertebr. Paleontol. New Mex., 2, 71-76, 1993. 
Iturralde-Vinent, M. and Ceballos-Izquierdo, Y.: Catalogue of Late Jurassic Vertebrate (pisces, reptilian) specimens from Western Cuba, Paleontol. Mex., 3, 24-39, 2015.

Lambers, P. H.: On the ichthyofauna of the Solnhofen Lithographic Limestone (Upper Jurassic, Germany), Ph.D. thesis Proefschrift Rijksuniversiteit Groningen, Netherlands, 336 pp., 1992.

Lambers, P. H.: The halecomorph fishes Caturus and Amblysemius in the Lithographic Limestone of Solnhofen (Thitonian), Bavaria, Geobios, 16, 91-99, 1994.

Lambers, P. H.: The monophyly of the Caturidae (Pisces; Actinopterygii) and the phylogeny of the Halecomorphi, Geobios, Mém. Sp. 19, 201-203, 1995.

Leanza, H. and Zeiss, A.: Upper Jurassic Lithographic Limestones from Argentina (Neuquén Basin): Stratigraphy and Fossils Oberjurassische lithographische Kalke aus Argentinien (Neuquén Becken): Stratigraphie und Fossilien, Facies, 22, 169-185, 1990.

Lehman, J. P.: Actinopterygii, in: Traité de Paléontologie IV (3), edited by: Piveteau, J., 1-242, Masson et Cie., Paris, 1966.

Liston, J. J.: The ocurrence of the Middle Jurassic pachycormid fish Leedsichthys, Oryctos, 9, 1-36, 2010.

Liston, J. J., Newbrey, M. G., Challands, T. J., and Adams, C. E.: Growth, age, and size of the Jurassic pachycormid Leedsichthys problematicus (Osteichthyes: Actinopterygii), in: Mesozoic Fishes 5 - Global Diversity and Evolution, edited by: Arratia, G., Schultze, H.-P., and Wilson, M. V. H., 145-1175, Verlag Dr. Friedrich Pfeil, 2013.

Lund, R.: An analysis of the propulsive mechanisms of fishes, with particular reference to some fossil actinopterygians, Ann. Carnegie Museum, 39, 195-218, 1967.

Martín-Abad, H. and Poyato-Ariza, F. J. A.: Historical patterns of distribution in Pycnodontiform and Amiiform fishes in the context of moving plates, Geol. Belgica, 16, 217-226, 2013a.

Martín-Abad, H. and Poyato-Ariza, F. J. B.: Amiiforms from the Iberian Peninsula: historic review and research prospects, in: Mesozoic Fishes 5 - Global Diversity and Evolution, edited by: Arratia, G., Schultze, H.-P., and Wilson, M. V. H., 73-86, Verlag Dr. Friedrich Pfeil, München, 2013b.

Müller, J.: Über den Bau und die Grenzen der Ganoiden und über das natürliche System der Fische, Bericht Akad. der Wissenschaften Berlin, 1844, 416-422, 1845.

Murray, A. M.: The Palaeozoic, Mesozoic, and Early Cenozoic fishes of Africa, Fish Fish., 1, 111-145, 2000.

Nybelin, O.: Zur morphologie und terminologie des schwanzskelettes der Actinopterygier, Ark. fur Zool., 15, 485-516, 1963.

Nybelin, O.: On the Caudal Skeleton in Elops with remarks on other Teleostean Fishes, Acta Regiae Soc. Sci. Litt. Gothobg., Zoologica, 1-76, 1971.

Nybelin, O.: The polyural skeleton of Lepisosteus and certain other actinopterygians, Zool. Scr., 6 (1963), 244, 1977.

Olsen, P. E.: The skull and pectoral girdle of the parasemoinotid fish Watsonulus eugnathoides from the Early Triassic Sakamena Group of Madagascar, with comments on the relationships of the holostean fishes, J. Vertebr. Paleontol., 4, 481-499, 1984.

Owen, R. B.: Paleontology or a systematic summary of extinct animals and their geological relations, Adam and Black, Edimburg, 420 pp., 1860.
Patterson, C.: Interrelationships of holosteans, in: Interrelationships of Fishes, edited by: Greenwood, P. H., Miles, R. S., and Patterson, C., 233-305, Zool. J. Linn. Soc., 1973.

Patterson, C. and Rosen, D. E.: Review of Ichthyodectiform and other Mesozoic teleost fishes and the theory and practice of classifying fossils, Bull. Am. Museum Nat. Hist., 158, 81-172, 1977.

Poyato-Ariza, F. J., Buscalioni, A. D., and Cartanyá, J.: The Mesozoic record of osteichthyan fishes from Spain, in: Mesozoic Fishes 2 - Systematics and Fossil Record, edited by: Arratia, G. and Schultze, H.-P., 505-533, Verlag Dr. Friedrich Pfeil, München, 1999.

Saint-Seine, M. P. and Casier, E.: Poissons fossiles des couches de Stanleyville (Congo). Deuxième partie. La faune marine des Calcaires de Songa, Ann. du Musée R. l'Afrique Cent. Tervuren, Belgique, 44, 1-52, 1962.

Sauvage, H. E.: Note sur quelques poissons du calcaire bitumineux d'Orbagnoux (Ain), Bull. la Soc. d'historie Nat. d'Autun, 7, 427-443, 1893.

Schaeffer, B. and Patterson, C.: Jurassic fishes from the western United States, with comments on Jurassic distribution, Am. Mus. Novit., 2796, 1-86, 1984.

Schultze, H.-P.: Morphologische und histologische Untersuchungen an Schuppen mesozoischer Actinopterygier (Uebergang von Ganoidzu Rundschuppen), neues Jahrb. für Geol. und Pal. Ab, 126, 232-314, 1966.

Schultze, H.-P.: The scales of Mesozoic actinopterygians, in: Mesozoic Fishes - Systematics and Paleoecology, edited by: Arratia, G. and Viohl, G., 83-93, Verlag Dr. Friedrich Pfeil, München, 1996.

Schultze, H.-P.: Scales, Enamel, Cosmine, Ganoine, and Early Osteichthyans, C. R. Palevol., 15, 83-102, 2016.

Schultze, H.-P. and Arratia, G.: Reevaluation of the caudal skeleton of actinopterygian fishes. I. Lepisosteus and Amia, J. Morphol., 190, 215-241, 1986.

Schultze, H. and Arratia, G.: The composition of the caudal skeleton of teleosts (Actinopterygil : Osteichthyes), Zool. J. Linn. Soc., 189-231, 1989.

Schultze, H.-P. and Arratia, G.: The caudal skeleton of basal teleosts, its conventions, and some of its major evolutionary novelties in a temporal dimension, in: Mesozoic Fishes 5 - Global Diversity and Evolution, 187-246, Verlag Dr. Friedrich Pfeil, München, 2013.

Schultze, H.-P. and Arratia, G.: Knochenfische im weiteren Sinne (Osteichthyes oder Osteognathostomata), in: Solnhofen ein Fenster in die Juraziet, 360-409, 2015.

von Zittel, K. A.: Handbuch der Palaeontologie, Palaezoologie, R. Oldenbourg, München and Leipzig, 1887.

Wagner, A.: Neue Beiträge zur Kenntniss der urweltlichen Fauna des lithographischen Schiefers, Abhandlungen der Math. Cl. der Königlich Bayer. Akad. der Wissenschaften, 611-748, 1863.

Wenz, S.: Complements a l'etude des poissons actinopterygiens du Jurassic Fraņcais, Cahiers du Paleontologie, Paris, 276 pp., 1967.

Woodward, A. S.: Actinopterygian Teleostomi of the Orders Chondrostei (concluded), Protospondyli, Aetheospokdyli, and Isospondyli (in part), Catalogue of the fossil fishes in the British Museum of Natural History, Longmans \& Co, 544 pp., 1895. 